\title{
POLIGAMI DALAM PERSPEKTIF UNDANG-UNDANG NOMOR I TAHUN 1974 TENTANG PERKAWINAN DAN KOMPILASI HUKUM ISLAM (KHI)
}

\author{
Esther Masri \\ Fakultas Hukum, Universitas Bhayangkara Jakarta Raya \\ esther.masri@yahoo.com
}

\begin{tabular}{|c|c|c|}
\hline Naskah diterima: & Revisi: & Naskah disetujui: \\
$25 / 07 / 2019$ & $12 / 08 / 2019$ & $20 / 08 / 2019$ \\
\hline
\end{tabular}

\begin{abstract}
Abstrak
Undang-Undang Nomor 1 Tahun 1974 Tentang Perkawinan dan Kompilasi Hukum Islam (KHI) mengatur mengenai seorang pria hanya boleh memiliki seorang istri dan seorang wanita hanya boleh memiliki seorang suami, yang dikenal dengan asas monogami. Asas monogami yang dimaksud bukanlah asas monogami mutlak tetapi asas monogami terbuka. Artinya, jika suami tidak mampu berlaku adil terhadap hak-hak istri bila lebih dari seorang maka cukup seorang istri saja. Poligami dibolehkan tentunya dengan pengecualian dan syarat-syarat tertentu. Tidak mudah untuk berpoligami karena keadilan adalah syarat mutlak dan yang terpenting harus dengan persetujuan istri. Kompilasi Hukum Islam juga mengatur ketentuan dan syarat untuk berpoligami bagi umat islam. Ketentuan-ketentuan yang terdapat dalam Undang-Undang perkawinan pada prinsipnya selaras dengan ketentuan hukum islam. Tujuan dari Undang-Undang Perkawinan dan Kompilasi Hukum Islam memberikan ketentuan dan persyaratan terhadap seorang suami untuk menikah lagi agar tidak terjadi sikap sewenang-wenang dari suami terhadap istri-istri (perempuan) demi terciptanya keluarga sakinah, mawaddah dan rahmah. Saat ini di Indonesia banyak terjadi kasus poligami yang tidak dijalankan sesuai prosedur dan bertentangan dengan ketentuan syariah yang dapat membawa kemudharatan terhadap istri dan anak-anak.
\end{abstract}

Kata Kunci : Poligami, Undang-Undang Nomor 1 tahun 1974, Kompilasi Hukum Islam

\begin{abstract}
Indonesian Law number 1 of the year 1974 on marriage law, as well as the Compilation of Islamic Law, regulate that a man may only have a wife and a woman may only have a husband, known as the monogamy principle. The principle of monogamy in question is not absolute monogamy but open monogamy. It means, that if the husband is not able to be fair to the rights of the wives in the manner the husband has another wife, then the husband may only have one wife. Polygamy is allowed with certain exception and conditions. To commit polygamy is not easy due to the strict fairness and permission from the wife/ wives. The Compilation of Islamic Laws also regulates the term and conditions for a man to be allowed to do polygamy. Policies on this matter, as stated in the Marriage Law is in line with the ones of the Islamic Law. The purpose of the Marriage Law and The Compilation of Islamic Law in regards to the polygamy is to protect the wife in the condition that the husband decides to take another wife or re-marry to another woman. It is to avoid negligence and unfairness towards the wives and to achieve the religious, prosperous, and blessed family.
\end{abstract}


Recently in Indonesia the are a lot of cases of unprocedural and unlawful polygamy that harm the lives of the wife/ wives and the children.

Keywords: Polygamy, Law number 1 of the year 1974, Compilation of Islamic Law

\section{Pendahuluan}

Perkawinan merupakan suatu peristiwa hukum yang sangat penting yang menjadi kebutuhan hidup seluruh umat manusia sejak zaman dahulu hingga saat ini. Perkawinan merupakan masalah yang aktual untuk dibicarakan di dalam maupun di luar peraturan hukum. Berdasarkan ketentuan Pasal 1 Undang-Undang Nomor 1 Tahun 1974 tentang Perkawinan, Perkawinan adalah ikatan lahir bathin antara seorang pria dan seorang wanita sebagai suami istri dengan tujuan membentuk keluarga atau rumah tangga yang bahagia dan kekal berdasarkan Ketuhanan Yang Maha Esa. Perkawinan adalah perikatan yang suci yang tidak terlepas dari agama yang dianut suami dan istri. Hidup bersama dalam perkawinan tidak hanya untuk memenuhi kebutuhan biologis saja tetapi untuk membentuk rumah tangga yang bahagia, rukun, dan harmonis. Dalam Pasal 2 (dua) Kompilasi Hukum Islam (KHI) disebutkan bahwa perkawinan menurut Hukum Islam adalah pernikahan yaitu akad yang sangat kuat atau mitssaqan ghalidzan untuk menaati perintah Allah dan melaksanakannya merupakan ibadah. ${ }^{1}$

Tujuan perkawinan dalam islam adalah untuk memenuhi tuntutan hajat tabiat kemanusiaan berhubungan dengan laki-laki dan perempuan dalam rangka mewujudkan suatu keluarga yang bahagia dengan dasar cinta dan kasih sayang untuk memperoleh keturunan yang sah dalam masyarakat dengan mengikuti ketentuan-ketentuan yang telah diatur oleh Syariah. ${ }^{2}$ Bagi umat islam, hukum perkawinan di Indonesia bersumber dari AlQur'an dan hadist yang tertuang dalam Undang-Undang Perkawinan Nomor 1 Tahun 1974 dan Kompilasi Hukum Islam (KHI) tahun 1991. Undang-Undang Perkawinan bertujuan untuk mewujudkan kehidupan rumah tangga yang sakinah, mawaddah, rahmah. ${ }^{3}$ Agar terciptanya kehidupan rumah tangga yang harmonis suami dan istri harus saling menyayangi dan mencintai untuk menjadikan perkawinannya kekal dan bahagia sesuai dengan tujuan perkawinan.

\footnotetext{
${ }^{1}$ Asmin, Status Perkawinan Antar Agama Ditinjau dari Undang-Undang Nomor. 1 Tahun 1974, Jakarta: Dian Rakyat, 1986, hlm 28.

${ }^{2}$ Soemiyati, Hukum Perkawinan Islam dan Undang-Undang Perkawinan, Yogyakarta: Liberty, cet. 6, 2007, hlm 73.

${ }^{3}$ Hilman Hadikusuma, Hukum Perkawinan Indonesia, Bandung: CV Mandar Maju, 2007, cet. III, hlm 4.
} 
Ikatan dalam perkawinan walaupun dikatakan kokoh tapi juga ada batasnya. Terkadang ikatan itu terlepas bahkan terurai baik karena kehendak masing-masing pihak dari suami dan istri atau disebabkan di luar dari kehendak mereka. Salah satu masalah perkawinan yang masih menjadi polemik yang menimbulkan pro dan kontra yang terjadi dalam masyarakat adalah poligami, yang merupakan suatu realita hukum di bidang perkawinan. Istilah poligami berasal dari bahasa Yunani yaitu Poli atau Polus yang berarti banyak dan gamein atau gamos yang berarti perkawinan. Poligami adalah suatu perkawinan yang terdiri dari seorang suami dan beberapa orang istri. Poligami dapat menimbulkan permasalahan sosial yang memicu pertengkaran dalam rumah tangga, perselingkuhan, perceraian antara suami istri dan terjadinya pernikahan di bawah tangan (pernikahan siri) yang sangat berdampak terhadap status istri dan anak-anak yang rela dipoligami secara tidak sah dan tentunya tidak diakui oleh negara. Sebagian berpendapat poligami adalah suatu dosa atau perbuatan yang salah untuk dilakukan, perbuatan yang tidak beradab dan tidak memuliakan perempuan, serta menganggap suatu kewajaran ketika seorang suami membagi cinta kepada wanita lain untuk menjadi pasangan hidup yang kedua. Islam menuntun manusia untuk menjauhi perselingkuhan dan telah mengatur secara sempurna mengenai perkawinan dan poligami. Tetapi saat ini banyak pelaku poligami yang hanya berdasarkan hawa nafsu belaka dan tidak sesuai dengan ketentuan agama.

Menurut pandangan Fazlur Rahman poligami merupakan produk hukum islam yang legal tujuannya untuk mencapai idealitas tatanan dalam sebuah komunitas tertentu. Karenanya poligami tidak dapat dihilangkan begitu saja. ${ }^{4}$ M. Quraish Shihab, seorang tokoh tafsir kontemporer menyatakan poligami adalah sebuah wadah bagi yang menginginkannya ketika seseorang menghadapi kondisi atau kasus tertentu yang menjadi alasan logis untuk melakukan poligami yang dibenarkan, meski dengan syarat yang tidak ringan dan tidak setuju jika poligami sebuah anjuran apalagi kewajiban, akan tetapi poligami sebuah solusi bagi sebuah kondisi darurat yang hanya bisa dibuka jika kondisi itu mengharuskan demikian. ${ }^{5}$

Ketentuan tentang poligami dalam Undang-Undang Perkawinan terdapat dalam Pasal 4 ayat (1) dan (2). Undang-Undang ini sebagai bentuk respon positif untuk mengatur seorang suami yang ingin menikah dengan lebih dari satu orang (istri). Poligami

\footnotetext{
${ }^{4}$ Fazlur Rahman, Tema Pokok Al-Qur'an, Terjemahan Anas Mahyuddin, Bandung: Pustaka, 1996, hlm 70-71. ${ }^{5}$ M. Quraish Shihab, Tafsir Al- Misbah, Pesan, Kesan dan Keserasian Al-Qur'an, Jakarta: Lentera Hati, 2006, hlm 342 .
} 
diperbolehkan dengan alasan, syarat dan prosedur tertentu tidak bertentangan dengan ajaran islam. Demikian juga dengan lahirnya Kompilasi Hukum Islam yang mengatur ketentuan poligami bagi umat Islam. Syarat utama poligami adalah harus adil terhadap istri baik dalam nafkah lahir dan bathin, perhatian terhadap keluarga dan rasa kasih sayang, perlindungan terhadap keluarga agar terciptanya hubungan yang harmonis. Demi kemaslahatan umum diperlukan adanya alasan-alasan terhadap perkawinan poligami. Misalnya, kemandulan seorang wanita yang kehilangan daya fisik atau mental akan banyak menyeret terjadinya perceraian dari pada poligami. Sudah sepatutnya istri yang demikian merelakan suaminya sebagai bukti tanggung jawabnya dalam rangka melestarikan kehidupan keluarga dan memakmurkan bumi. ${ }^{6}$

Pasal 3 ayat (1) Undang-undang Perkawinan menjelaskan bahwa hukum perkawinan di Indonesia menganut asas monogami yang menyatakan seorang pria hanya boleh memiliki seorang istri dan seorang wanita hanya boleh memiliki seorang suami. Namun, pada bagian yang lain dinyatakan bahwa dalam keadaan tertentu poligami dibenarkan seperti yang dimaksud dalam Pasal 3 ayat 2 (dua) bahwa Pengadilan dapat memberi izin kepada seorang suami untuk beristri lebih dari seorang apabila dikehendaki oleh pihak-pihak yang bersangkutan. Dalam hal ini berarti pengadilan dapat memberikan izin kepada seseorang untuk berpoligami apabila adanya persetujuan dari istri.

Dalam islam para ulama termasuk mufassir klasik pada umumnya mengakui poligami sebagai norma islam yang secara tekstual mendapat legitimasi Al-Quran. Di sisi lain dengan berbagai argumentasinya mayoritas pemikir islam modern berpendapat bahwa monogami merupakan tujuan ideal islam dalam perkawinan. ${ }^{7}$ Menurut Amina Wadud Muhsin, dengan monogami tujuan utama pernikahan untuk membentuk keluarga yang penuh cinta kasih dan tentram dapat dipenuhi. Sementara dalam poligami hal itu tidak mungkin akan tercapai disebabkan seorang suami atau ayah akan membagi cintanya kepada lebih dari satu keluarga. ${ }^{8}$

\section{Sejarah Poligami}

\footnotetext{
${ }^{6}$ Huzaimah T. Yanggo dan H. Anshari, Problematika Hukum Islam Kontemporer, Jakarta: Lembaga Studi Islam dan Kemasyarakatan, 1996, hlm 108-109.

${ }^{7}$ Inayah Rochmaniyah, Poligami atau Monogami: Menggagas Penafsiran Ashgar Ali Terhadap Qur'an Surat An-Nisaa, dalam jurnal Studi Ilmu-ilmu Al Qur'an dan Hadist, Vol 2 no. 1, 2001, hlm 57.

${ }^{8}$ Amina Wadud Muhsin, Wanita di dalam Al-Qur'an, Terjemahan Yaziar Radianti, Bandung: Pustaka, 1994, hlm 111.
} 
Poligami telah ada sejak jauh sebelum datangnya islam. Orang-orang Eropa yang sekarang kita sebut Rusia, Yugoslavia, Cekoslovakia, Jerman, Belgia, Denmark, Swedia dan Inggris semuanya adalah bangsa-bangsa yang berpoligami. Demikian juga bangsa-bangsa timur seperti Ibrani dan Arab. ${ }^{9}$ Sebelum datangnya islam masyarakat (Arab khususnya) sebenarnya sudah mengenal dan mempraktikkan poligami. Tidak sedikit diantara mereka yang memiliki istri lebih dari satu. Ada yang memiliki lima orang istri, delapan orang istri bahkan ada juga yang memiliki istri lebih dari itu. ${ }^{10}$

Poligami bukan semata-mata produk syariat islam. Jauh sebelum islam lahir pada tahun 610 Masehi, peradaban manusia di penjuru dunia sudah mengenal poligami. Dr. Yusuf Al-Qardhawi menuliskan bahwa di masa lalu, peradaban manusia sudah mengenal poligami dalam bentuk yang sangat mengerikan, karena seorang laki-laki bisa saja memiliki bukan hanya 4 (empat) istri tapi lebih dari itu. Ada yang sampai 10 (sepuluh) bahkan ratusan istri. Bahkan dalam kitab orang Yahudi perjanjian lama, Daud disebutkan memiliki 300 orang istri, baik yang menjadi istri resminya maupun selirnya. ${ }^{11}$ Dalam fiqhus-Sunah As-Sayyid Sabiq dengan mengutip kitab hak-hak wanita dalam islam karya Ustadz Dr. Ali Abdul Wahid Wafi menyebutkan bahwa poligami bila kita runut dalam sejarah sebenarnya merupakan gaya hidup yang diakui dan berjalan dengan lancar di pusat-pusat peradaban manusia. Bisa dikatakan bahwa hampir semua pusat peradaban manusia terutama yang maju dan berusia panjang mengenal poligami dan mengakuinya sebagai sesuatu yang normal dan formal.

Para ahli sejarah mendapatkan bahwa hanya peradaban yang tidak terlalu maju saja dan tidak berusia panjang tidak mengenal poligami. Poligami bukanlah milik peradaban masa lalu dunia tetapi hari ini masih tetap diakui oleh negeri dengan sistem hukum yang bukan islam seperti Afrika, India, China dan Jepang. Sehingga jelaslah poligami adalah produk umat manusia, produk kemanusiaan dan produk peradaban besar dunia. Islam hanyalah salah satu yang ikut di dalamnya dengan jiwa manusia. Islam datang dalam kondisi dimana masyarakat dunia telah mengenal poligami selama ribuan tahun dan telah diakui dalam sistem hukum umat manusia. Justru islam memberikan aturan agar poligami itu tetap selaras dengan rasa keadilan dan keharmonisan. Misalnya, dengan mensyaratkan adanya keadilan dan kemampuan dalam nafkah. Begitu juga islam sebenarnya tidak membolehkan

\footnotetext{
${ }^{9}$ Alhamdani, Risalah Nikah, Jakarta: Pustaka Armani, cet. III, 1989, hlm 79.

${ }^{10}$ Iffah Qanita Nailiya, Poligami, Berkah ataukah Musibah?, Yogyakarta: Diva Press, 2016, hlm 17.

${ }^{11}$ Yusuf Al-Qardhawi, Ruang Lingkup Aktivitas Wanita Muslimah, cet. 1, Jakarta: Pustaka al-Kautsar, 1996, hlm 184
} 
poligami secara mutlak, sebab yang dibolehkan hanya sampai empat orang istri dan segudang aturan main lainnya sehingga meski mengakui adanya poligami namun poligami yang berkeadilan sehingga melahirkan kesejahteraan. ${ }^{12}$

\section{Poligami di Negara Islam}

Dalam islam poligami diperbolehkan tetapi harus memenuhi ketentuan syariah. Prinsip dasar kebolehan poligami banyak disalahgunakan oleh berbagai pihak. Karena itulah pemerintah membuat aturan yang membatasi kebolehan poligami agar hak-hak dan kemuliaan perempuan terjaga dan terlindungi.

Ada 3 (tiga) kelompok negara mayoritas penduduknya muslim dalam menyikapi poligami :

1. Negara yang melarang poligami

Tunisia dengan Undang-Undang Keluarga (Code of Personal Status/ Majalat al Ahwal al Syakhsiyyah No. 66 Tahun 1956) yang ditetapkan tahun 1957 oleh Presiden Habib Borgoibe, melarang poligami secara mutlak dan menghukum orang yang melanggar aturan poligami. Bahkan pada tahun 1964 pelaku poligami bukan saja dapat dikenakan hukuman tetapi dinyatakan perkawinannya tidak sah. 2 (dua) alasan Tunisia melarang poligami yaitu

a. Institusi budak dan poligami hanya boleh pada masa perkembangan tetapi dilarang setelah menjadi masyarakat berbudaya.

b. Surat An-Nisa (4):3, menetapkan bahwa syarat mutlak seorang suami boleh berpoligami apabila dapat berbuat adil terhadap istri-istrinya. Sementara fakta sejarah membuktikan hanya Nabi yang dapat berlaku adil terhadap istri-istrinya.

Tunisia adalah negara muslim ketiga setelah Turki dan Lebanon yang melarang poligami secara mutlak. Dalam Undang-Undang Status Personal Tunisia tahun 1956 terutama dalam Pasal 18 menyatakan: ${ }^{13}$

"Bahwasanya beristri lebih dari seorang adalah dilarang. Setiap orang yang telah masuk dalam satu ikatan perkawinan lalu menikah lagi sebelum yang terdahulu bubar secara hukum, maka ia dapat dikenakan hukuman penjara selama satu tahun atau denda 240.000 malim atau kedua-duanya."

2. Negara yang membatasi poligami

Dalam rangka melindungi dan menjamin hak-hak perempuan dan anak-anak, pada umumnya negara-negara muslim memberikan pengaturan mengenai kebolehan poligami yang diperketat dengan sejumlah persyaratan sehingga sulit dipenuhi oleh seorang laki-laki.

\footnotetext{
${ }^{12}$ Ahmad Sarwat, Ensiklopedia Fikih Indonesia 8: Pernikahan, Jakarta: PT. Gramedia Pustaka Utama, 2019, hlm 346-347.

${ }^{13}$ Tahir Mahmood, Personal Law In Islamic Countries, History, Text, and Comparative, Analysis, Academy of Law and Religion, 1987, hlm 156.
} 
Di Indonesia, Irak, Malaysia, Somalia dan Suriah seorang suami yang hendak melakukan poligami harus mendapat izin terlebih dahulu dari pengadilan. Sementara di Bangladesh dan di Pakistan izin tersebut juga diharuskan dan diperoleh dari semacam Dewan Arbitrase.

Di Irak dan Suriah izin poligami dapat diberikan jika terdapat alasan yang kuat dan sah. Di Pakistan, Bangladesh dan Malaysia izin poligami diberikan jika suami dipandang oleh pengadilan mampu berlaku adil. Bahkan di Malaysia menambahkan ketentuannya bahwa harus dipastikan para istri tidak mendapat mudharat atau bahaya yang diakibatkan adanya poligami. Di Indonesia, Somalia, dan Yaman Selatan pengadilan dapat memberikan izin untuk poligami jika istri menderita mandul, cacat fisik atau penyakit yang tidak dapat disembuhkan atau istri tidak dapat menjalankan tugasnya dengan baik. Di Yaman Selatan juga ada ketentuan boleh berpoligami jika istri di penjara lebih dari 2 tahun. Kemampuan finansial suami juga menjadi bahan pertimbangan dalam memberikan izin oleh pengadilan. 3. Negara yang menyikapi poligami secara biasa

Saudi arabia, Qatar, Kuwait dan Oman adalah negara yang menyikapi poligami secara biasa karena dengan pertimbangan sudah diatur dalam kitab-kitab fiqih dan tidak seharusnya negara banyak tangan dalam hal ini, pengaturan poligami lebih banyak diserahkan kepada pelaku dan ketentuan fiqih yang sudah mapan.

\section{Poligami dalam Pandangan Barat}

Perdebatan poligami tidak hanya terjadi dikalangan umat islam. Penganut di luar islam juga memberikan pendapat mengenai poligami. Masyarakat Barat (Eropa dan Amerika) memandang bahwa poligami merupakan sistem pernikahan yang akan membuat pertentangan dan perpecahan antara suami, istri dan anak-anak. Poligami mengikis kemuliaan perempuan yang mana perempuan seakan tidak memiliki hak untuk mempertahankan suaminya agar tidak berbagi dengan perempuan lain. Masyarakat barat meyakini bahwa monogami sebagai sistem perkawinan ideal namun dalam kenyataannya banyak penyimpangan yang terjadi dengan melakukan poligami yang tidak resmi. Ketentuan agama mereka dan undang-undangnya melarang keras praktik poligami. Tetapi kenyataannya dalam sistem hukum dan moral mereka malah membolehkan terjadinya perzinaan, homoseksual, lesbianisme dan gonta-ganti pasangan suami istri. Padahal semua pasti tahu poligami jauh lebih beradab dari semua itu.

Dr. Yusuf Al-Qardhawi mengatakan bahwa pada hakikatnya apa yang dilakukan oleh masyarakat barat pada hari ini dengan segala bentuk perzinaan yang mereka lakukan tidak lain adalah suatu bentuk poligami juga meski tidak dalam bentuk formal. Dan 
kenyataannya mereka memang terbiasa melakukan hubungan seksual di luar nikah dengan siapapun yang mereka inginkan. Di tempat kerja, hubungan seksual di luar nikah menjadi sesuatu yang lazim dilakukan mereka baik sesama teman kerja, antara atasan dan bawahan, ataupun klien mereka. Di tempat umum mereka terbiasa melakukan hubungan seksual di luar nikah baik dengan wanita penghibur, pelayan restoran, artis, dan selebritis. Di sekolah pun mereka menganggap wajar bila terjadi hubungan seksual baik sesama pelajar, antara pelajar dengan guru atau dosen, antar karyawan dan seterusnya. Bahkan di dalam rumah tangga pun mereka menganggap boleh dilakukan dengan tetangga, pembantu rumah tangga, sesama anggota keluarga atau dengan tamu yang menginap. Semua itu bukan mengada-ada karena secara jujur dan polos mereka akui sendiri dan tercermin dalam film-film Hollywood dimana hampir selalu dalam setiap kesempatan mereka melakukan hubungan seksual dengan siapapun.

Jadi, peradaban barat membolehkan poligami dengan siapa saja tanpa batas bisa dengan puluhan bahkan ratusan orang yang berlainan. Sangat besar kemungkinan merekapun telah lupa dengan siapa saja pernah melakukannya, semua itu terjadi begitu saja tanpa pertanggung jawaban, tanpa ikatan, tanpa konsekuensi, dan tanpa pengakuan. Apabila terjadi kehamilan, sama sekali tidak ada konsekuensi hukum untuk mewajibkan bertanggung jawab atas perbuatan itu. Poligami tidak formal alias seks diluar nikah itu alih-alih dilarang, malah sebaliknya dilindungi dan dihormati sebagai hak asasi. Lucunya banyak negara yang mengharamkan poligami formal yang mengikat dan menuntut tanggung jawab, sebaliknya seks bebas yang tidak lain merupakan bentuk poligami yang tidak bertanggung jawab malah dibebaskan, dilindungi dan dihormati. ${ }^{14}$

\section{Faktor-faktor penyebab terjadinya poligami beserta dampaknya}

Realitas perkawinan poligami sudah sejak dulu mewarnai struktur kehidupan dalam suatu keluarga. Keluarga yang berpoligami adalah keluarga yang unik dan eksklusif karena tidak semua orang mampu untuk melakukan dan melaluinya serta harus matang dalam mengambil keputusan. Pada dasarnya keinginan untuk berpoligami bukan sesuatu hal yang direncanakan, bahkan seseorang juga tidak menginginkan kondisi kehidupan perkawinan seperti itu, tetapi banyak faktor baik internal maupun eksternal yang dapat mempengaruhi keinginan seseorang untuk melakukan poligami.

\footnotetext{
${ }^{14}$ Ahmad Sarwat, op.cit., hlm 348.
} 
Poligami dapat dilakukan oleh semua golongan baik golongan kaya atau miskin. Pelaku poligami dengan berbagai macam jenis pekerjaan, golongan, suku, bangsa dan pendidikan. Mereka melakukan dengan berbagai macam alasan dan kebanyakan seseorang berpoligami tidak sesuai dengan ketentuan syariah.

\section{Kebutuhan Biologis}

Ketidakmampuan mengendalikan hawa nafsu dan tidak mampu menjaga pandangannya maka manusia akan menempati posisi yang terendah. Poligami yang terjadi saat ini justru berawal dari perselingkuhan. Dari mata turun ke hati sehingga menimbulkan rasa saling mencintai dan menjadi sesuatu yang wajar berhubungan dengan wanita lain yang bukan istri sahnya. Apalagi dengan komunikasi yang baik dan terus menerus. Seseorang dapat berkomunikasi kapan saja dan dimanapun berada. Diawali dengan perkenalan hingga ke tahap serius selanjutnya.

Secara fitrah, umumnya kebutuhan seksual laki-laki lebih tinggi dari wanita. Cara pemenuhan terhadap nafsu dan kebutuhannya berbeda-beda. Dari sudut pandang laki-laki, masalah pemenuhan seks sedikit banyaknya dipengaruhi dengan adanya kepuasan hubungan seksual dan bisa terpenuhi bila kepuasan itu didapat. Umumnya laki-laki membutuhkan kepuasan seksual baik dalam kualitas maupun kuantitas. Tapi lebih dominan kepuasan secara kualitas. Sementara istri kurang mampu memberikannya baik dari segi kualitas maupun kuantitas. Akhirnya terjadi ketidakseimbangan dalam pemenuhan kebutuhan biologis suami istri. Apalagi tidak dikomunikasikan dengan baik dan terbuka. Maka akhirnya menikah dengan berpoligami menjadi alternatif solusi.

Kebutuhan biologis merupakan kebutuhan yang esensial dalam perkawinan. Perkawinan dapat menjadi jalan mewujudkan dorongan seks bagi pasangan suami istri. Apabila pemenuhan kebutuhan ini tidak berjalan dengan baik sebagaimana yang diharapkan maka muncul keinginan untuk mendapatkan pasangan lain diluar perkawinan yang sah.

2. Status sosial, adat dan budaya

Status sosial laki-laki menentukan jumlah istri yang dimiliki. Banyak orang tua yang rela dan menawarkan anak perempuannya untuk diperistri oleh laki-laki yang dewasa, mapan dan mempunyai jabatan tentunya sudah mempunyai istri. Dengan tujuan untuk meningkatkan derajat dan status sosial walaupun pernikahan yang dilakukan dengan pernikahan siri atau pernikahan di bawah tangan.

Masih kentalnya adat dan budaya dalam masyarakat, merupakan salah satu sebab terjadinya poligami. Poligami yang sering terjadi pada masyarakat patrilineal dan tidak dapat 
dipungkiri banyak juga terdapat pada masyarakat dengan sistem matrilineal dan parental. Berbagai faktor penyebab poligami dalam masyarakat berakibat tidak dilakukan permohonan izin poligami melalui Pengadilan Agama karena dengan alasan merasa malu dan tidak berani untuk meminta persetujuan dari istri yang sah sehingga poligami dirahasiakan, sudah cukup terpenuhi rukun pernikahan, kurang pengetahuan, tidak mau berhubungan dengan masalah birokrasi dan biaya mahal.

\section{Ekonomi}

Kemapanan dalam ekonomi bagi laki-laki sangat rentan untuk melakukan poligami dan marak dilakukan dikalangan masyarakat yang berpenghasilan besar.

\section{Agama}

Pelaku poligami berpendapat bahwa poligami dibolehkan oleh agama. Sebenarnya islam tidak menyuruh seseorang untuk berpoligami tetapi Hukum Islam hanya memberikan aturan, ketentuan tentang persyaratan poligami yang wajib dipatuhi. Saat ini banyak sekali yang berdalih untuk melakukan poligami dengan membawa nama agama. Padahal dalam islam sudah jelas ditegaskan boleh berpoligami apabila sesuai dengan yang disebutkan dalam Pasal 3 ayat (2) dan Pasal 4 ayat (2) Undang-Undang Perkawinan dan ketentuannya juga terdapat dalam Kompilasi Hukum Islam (KHI). Dalam Undang-Undang Perkawinan dan Kompilasi Hukum Islam (KHI) suami melakukan poligami harus atas persetujuan istri tetapi kenyataannya saat ini istri justru tidak mengetahui suaminya berpoligami dengan melakukan pernikahan dibawah tangan (pernikahan siri) yang sangat berdampak merugikan istri dan anak-anak.

Dampak poligami

a. Dampak Psikologis

Menjalani poligami diperlukan kesiapan fisik, psikis juga ruhiyah dari suami, istri dan juga seluruh pihak keluarga. Istri yang tidak bisa menerima kenyataan bahwa suami telah berpoligami pada umumnya akan mengalami kelabilan emosi, istri menjadi sensitif, mudah marah, sikap yang tidak terkontrol karena emosinya, yang lebih sering mudah sedih dan sering curiga berlebihan. ${ }^{15}$ Perasaan selalu menyalahkan diri sendiri karena ketidakmampuan dalam memberikan pelayanan yang baik dan tidak bisa memenuhi kebutuhan biologis suami. Poligami tidak hanya berdampak kepada istri tetapi juga kepada anak. Pada dasarnya anak berharap memiliki keluarga yang ideal satu ayah dan satu ibu.

\footnotetext{
${ }^{15}$ Soewondo, S, Keberadaan Pihak Ketiga, Poligami dan Permasalahan Perkawinan (Keluarga) Ditinjau Dari Aspek Psikologi, dalam Munandar, (ed), Bunga Rampai, Psikologi Perkembangan Kepribadian dari Bayi sampai lanjut usia, Jakarta: UI Press, 2001), hlm 154-184.
} 
Hadirnya keluarga lain dalam kehidupannya dapat memicu rasa kecewa dan trauma terhadap anak karena perhatian seorang ayah sudah terbagi untuk keluarganya yang lain menyebabkan anak kurang kasih sayang. Poligami juga dapat berdampak terjadinya perceraian karena komunikasi yang tidak berjalan dengan baik.

b. Dampak ekonomi

Sulitnya mengukur kadar keadilan yang dimiliki. Suami lebih mementingkan istri muda mengenai pemberian nafkah materiil. Tapi tidak jarang juga suami yang peduli dan adil dalam memberikan nafkah secara ekonomi. Sifat ketergantungan istri yang tidak bekerja dalam hal ekonomi membuat istri menerima dan pasrah terhadap poligami yang telah dilakukan suaminya.

c. Dampak Hukum

1. Maraknya pernikahan di bawah tangan atau pernikahan siri. Pernikahan secara agama sah tetapi tidak diakui negara. Pernikahan yang tidak tercatat di Kantor Urusan Agama (KUA) karena dilakukan dengan sembunyi-sembunyi dan dirahasiakan. Dalam Pasal 2 ayat (2) Undang-Undang Perkawinan sudah jelas dinyatakan bahwa tiap-tiap perkawinan dicatat menurut peraturan perundang-undangan yang berlaku. Konsekuensi dari pernikahan di bawah tangan akan muncul kasus perceraian di bawah tangan pula karena tidak memiliki buku (akta) nikah. Untuk mendaftarkan perkara di pengadilan harus dengan menyertakan buku (akta) nikah.

2. Terjadi pemaksaan kepada istri untuk memberi izin poligami. Jika istri tidak memberikan izin maka banyak terjadi pemalsuan identitas.

3. Berdampak terhadap pembuatan akta kelahiran anak. Dalam akta kelahiran anak hanya tertera nama ibunya saja. Untuk membuat akta kelahiran anak dibutuhkan buku (akta) nikah orang tua dari anak tersebut sedangkan suami istri tidak memiliki buku (akta) nikah karena suami telah melakukan poligami yang tidak sesuai dengan prosedur dan persyaratan yang telah ditentukan oleh undang-undang dan syariat islam. Jadi istri kedua dan anaknya tidak mempunyai hak dan kewajiban yang sama dengan istri pertama yang melakukan pernikahan secara sah dan sesuai dengan prosedur perundang-undangan. Apabila suami melakukan poligami dengan mematuhi aturan perundang-undangan maka hak dan kewajiban istri kedua dan anak sama dengan hak dan kewajiban dari istri pertama.

Terjadi masalah pembagian harta bersama baik harta perkawinan yang berkaitan dengan suami atau istri dan anak-anak. Hal ini sering terjadi karena merupakan masalah yang sangat urgen untuk diselesaikan dengan baik. Penyelesaian pembagian harta bersama ini bertujuan 
untuk menghindari perebutan harta kekayaan yang ditinggalkan oleh suami. Jika terjadi perebutan harta maka perkawinan poligami ini hanya akan mendatangkan mudharat yaitu perselisihan antara para istri dan akan menimbulkan kebencian sekaligus permusuhan. ${ }^{16}$

\section{Poligami dalam Undang-Undang Nomor 1 Tahun 1974 Tentang Perkawinan}

Perkawinan dan permasalahannya di Indonesia secara yuridis formal diatur dalam Undang-Undang Nomor 1 Tahun 1974 tentang Perkawinan, Peraturan Pemerintah Nomor. 9 Tahun 1975 tentang Pelaksanaan Undang-Undang Nomor. 1 Tahun 1974 dan Kompilasi Hukum Islam (KHI) sebagai pedoman bagi umat muslim di Indonesia. Salah satu asas perkawinan menurut sistem hukum Indonesia adalah asas monogami artinya oleh hukum yang berlaku di Indonesia seorang pria hanya boleh memiliki seorang istri, begitu juga sebaliknya seorang wanita hanya boleh memiliki seorang suami. Terhadap asas monogami ini oleh hukum dibuka kekecualian artinya dalam hal-hal yang sangat khusus, berpoligami (beristri lebih dari satu orang dalam waktu yang bersamaan) masih diperbolehkan asalkan memenuhi syarat, alasan dan prosedur tertentu. ${ }^{17}$ Prinsip ini ditegaskan dalam Pasal 3 ayat (1) Undang-Undang Perkawinan. Asas dalam Undang-Undang Perkawinan adalah bukan monogami mutlak tetapi asas monogami terbuka yang ditegaskan dalam Undang-Undang Perkawinan Pasal 3 ayat (2) yaitu Pengadilan dapat memberi izin kepada seorang suami untuk beristri lebih dari seorang apabila dikehendaki oleh pihak-pihak yang bersangkutan. Pasal 3 ayat (2) ini melibatkan Pengadilan Agama sebagai institusi yang cukup penting untuk mengesahkan kebolehan poligami.

Dalam hal ini yang merupakan syarat-syarat hukum agar seorang laki-laki dapat kawin dengan lebih dari satu orang istri dalam jangka waktu yang bersamaan (berpoligami) sebagai berikut:

5. Apabila beristri lebih dari satu memang dimungkinkan oleh agama dari mereka yang hendak melakukan perkawinan tersebut.

6. Apabila istri yang sudah ada dan istri yang hendak dikawini tersebut tidak melebihi jumlah yang dibenarkan oleh agama yang dianut oleh mereka yang hendak melakukan perkawinan tersebut.

7. Dalam hal seorang suami beristri lebih dari satu, maka suami wajib mengajukan permohonan kepada pengadilan di daerah tempat tinggalnya (Pasal 4 ayat 1 Undang-

\footnotetext{
${ }^{16}$ Aulia Muthiah, Dinamika Seputar Hukum Keluarga, Yogyakarta: Pustaka Baru Press, 2016, hlm 143.

${ }^{17}$ Munir Fuady, Konsep Hukum Perdata, Jakarta: Raja Grafindo Persada, cet 2, 2015, hlm 11.
} 
Undang Perkawinan). Ini merupakan syarat-syarat alternatif yang harus dipenuhi oleh pemohon. Dalam pasal 4 ayat (2) nya dijelaskan lebih lanjut bahwa pengadilan hanya akan memberikan izin kepada suami yang akan beristri lebih dari seorang apabila : ${ }^{18}$

a. Istri tidak dapat menjalankan kewajibannya sebagai istri.

b. Istri mendapat cacat badan atau penyakit yang tidak dapat disembuhkan.

c. Istri tidak dapat melahirkan keturunan.

8. Lebih lanjut juga diatur dalam Pasal 5 ayat (1) Undang-Undang Perkawinan, untuk dapat mengajukan permohonan ke Pengadilan untuk beristri lebih dari satu orang harus memenuhi syarat-syarat sebagai berikut :

a. Adanya persetujuan dari istri/istri-istri.

b. Adanya kepastian bahwa suami mampu menjamin keperluan-keperluan hidup istriistri dan anak-anak mereka.

c. Adanya jaminan bahwa suami akan berlaku adil terhadap istri-istri dan anak-anak mereka.

Pasal 5 ayat (2) disebutkan Persetujuan yang dimaksud dalam ayat 1 huruf (a) Pasal ini tidak diperlukan bagi seorang suami apabila isteri/isteri-isterinya tidak mungkin dimintai persetujuannya dan tidak dapat menjadi pihak dalam perjanjian atau apabila tidak ada kabar dari istrinya selama sekurang-kurangnya 2 (dua) tahun atau karena sebabsebab lainnya yang perlu mendapat penilaian dari hakim pengadilan. Apabila alasan dan syarat hukum telah terpenuhi, maka prosedur berpoligami tersebut harus dilakukan melalui pengadilan yakni dengan dikeluarkannya izin berpoligami oleh pengadilan yang berwenang. Persyaratan dalam Pasal 5 (lima) ini merupakan syarat kumulatif dimana seluruhnya harus dapat dipenuhi suami yang akan melakukan poligami.

Berdasarkan hal tersebut di atas, sudah jelas menunjukkan 3 (tiga) alasan yang dijadikan dasar pengajuan permohonan poligami. Tidak mudah untuk suami melakukan poligami, karena poligami bukan perintah agama tetapi hanya dibolehkan dengan beberapa syarat-syarat yang harus dipenuhi. Salah satu asas dalam Undang-Undang Perkawinan adalah poligami diperketat artinya suami harus meminta persetujuan istri terlebih dahulu jika akan melakukan poligami. Masalahnya, hal ini jarang bahkan tidak bisa dilakukan karena khawatir istri tidak memberikan izin sehingga banyak melakukan pemalsuan identitas agar dapat dilakukan pernikahan poligaminya. Ini merupakan suatu pelanggaran hukum. Pada umumnya poligami dilakukan dengan sembunyi-sembunyi dan dirahasiakan dan tidak

\footnotetext{
${ }^{18}$ Republik Indonesia, Undang-Undang Nomor. 1 Tahun 1974 Tentang Perkawinan.
} 
dilakukan pencatatan perkawinan. Pelaku poligami menikahi istri kedua, ketiga di bawah tangan atau secara nikah siri tanpa persetujuan istri pertama. Hal ini sudah tentu melanggar pasal 2 ayat (2) Undang-Undang Perkawinan yang dinyatakan, tiap-tiap perkawinan dicatat menurut peraturan perundang-undangan yang berlaku. Jadi ada 2 (dua) pelanggaran yang dilakukan oleh seorang suami yaitu tindakan suami yang menentang poligami yang membutuhkan dan mengharuskan izin dari istri pertama melalui pengadilan dan di sisi lain perkawinan di bawah tangan dapat dipertanyakan. Bagi istri kedua akan menghadapi masalah legalitas perkawinan dan status anak dari perkawinan tersebut.

Fenomena poligami saat ini banyak dilakukan atas dasar cinta diawali perkenalan dengan wanita lain sampai ke tahap yang dilarang oleh agama. Padahal istri tidak dalam keadaan sakit dan tidak kurang apapun dalam pelayanan di rumah tangga bahkan mempunyai anak bukan karena tidak mendapat keturunan. Dalam undang-undang alasan berpoligami harus jelas apabila alasan poligami karena istri sakit, tidak bisa memberikan keturunan suami harus dapat menunjukkan bukti surat keterangan medis yang menguatkan dalih tersebut. Keterangan medis dikeluarkan dari rumah sakit pemerintah atas permintaan pengadilan. Suami juga harus diperiksa kesuburannya karena belum tentu istri yang tidak subur dengan kata lain kemampuan melahirkan tergantung kepada kesuburan suami. Agar tidak terjadi kondisi yang saling menyalahkan satu sama lain.

\section{Poligami ditinjau dari Kompilasi Hukum Islam (KHI)}

Selain diatur dalam Al-Qur'an dan Hadis Nabi, perkawinan menurut hukum islam ini diatur pula dalam Instruksi Presiden Nomor. 1 Tahun 1991 tentang Kompilasi Hukum Islam (KHI). Secara umum, peraturan mengenai poligami dalam Kompilasi Hukum Islam (KHI) dapat dibedakan menjadi 2 (dua) yaitu pengaturan mengenai syarat-syarat poligami dan pengaturan mengenai proses poligami. ${ }^{19}$ Pengaturan poligami dalam Kompilasi Hukum Islam terdapat dalam Pasal 55 sampai Pasal 59 KHI. Pasal 55 menyatakan bahwa beristri lebih dari satu orang pada waktu yang bersamaan, terbatas hanya sampai 4 (empat) orang istri. Syarat utama beristri lebih dari seorang, suami harus mampu berlaku adil terhadap istriistri dan anak-anaknya. Apabila syarat utama ini tidak dipenuhi maka suami dilarang beristri lebih dari seorang.Suami yang beristri lebih dari satu orang harus mendapat izin dari Pengadilan Agama. Perkawinan yang dilakukan dengan istri kedua, ketiga atau keempat

\footnotetext{
${ }^{19}$ Jaih Mubarok, Pembaruan Hukum Perkawinan Di Indonesia, Bandung: Simbiosa Rekatama Media, 2015, hlm 159.
} 
tanpa izin dari Pengadilan Agama tidak mempunyai kekuatan hukum tetap (Pasal 56 KHI). Menurut Pasal 57 KHI Pengadilan Agama hanya memberikan izin kepada seorang suami yang akan beristri lebih dari seorang apabila $:^{20}$

a. Istri tidak dapat menjalankan kewajiban sebagai istri.

b. Istri mendapat cacat badan atau penyakit yang tidak dapat disembuhkan.

c. Istri tidak dapat melahirkan keturunan.

Selain syarat-syarat diatas, dalam Pasal 58 KHI disebutkan untuk memperoleh izin dari Pengadilan Agama harus pula memenuhi syarat-syarat sebagai berikut : ${ }^{21}$

a. Adanya persetujuan dari istri/ istri-istri.

b. Adanya kepastian bahwa suami mampu menjamin keperluan hidup istri-istri dan anakanak mereka.

c. Adanya jaminan bahwa suami akan berlaku adil terhadap istri-istri dan anak-anak mereka.

Mengenai persetujuan istri atau istri-istri ini dapat diberikan secara tertulis atau dengan lisan, tetapi sekalipun telah ada persetujuan tertulis, persetujuan ini dipertegas dengan persetujuan lisan istri pada sidang Pengadilan Agama. Persetujuan istri ini tidak diperlukan bagi seorang suami apabila istri atau istri-istrinya tidak mungkin dimintai persetujuannya dan tidak dapat menjadi pihak dalam perjanjian atau apabila tidak ada kabar dari istri atau istri-istrinya sekurang-kurangnya 2 (dua) tahun atau karena sebab lain yang perlu mendapat penilaian (Pasal $58 \mathrm{KHI}$ ), selanjutnya menurut Pasal $59 \mathrm{KHI}$, dalam hal istri tidak mau memberikan persetujuan dan permohonan izin untuk beristri lebih dari satu orang berdasarkan atas salah satu alasan yaitu :

a. Suami tidak mampu berlaku adil terhadap istri-istri dan anak-anaknya.

b. Istri tidak dapat menjalankan kewajiban sebagai istri.

c. Istri mendapat cacat badan atau penyakit yang tidak dapat disembuhkan.

d. Istri tidak dapat melahirkan keturunan.

Pengadilan Agama dapat menetapkan tentang pemberian izin setelah memeriksa dan mendengar istri yang bersangkutan di persidangan Pengadilan Agama dan terhadap penetapan ini istri atau suami dapat mengajukan banding atau kasasi. Jadi hukum islam memperbolehkan seorang suami beristri lebih dari seorang (poligami) asal sesuai dengan syarat- syarat hukum yang berlaku dan sesuai dengan ketentuan agama islam.

Dalam berpoligami Muhammad Abduh mengatakan bahwa meskipun hukum islam membuka jalan untuk berpoligami, namun jalan ini sebenarnya disempitkan sehingga

\footnotetext{
${ }^{20}$ Instruksi Presiden nomor. 1 Tahun 1991 tentang Kompilasi Hukum Islam.

${ }^{21}$ Ibid
} 
poligami hanya dapat dibenarkan untuk dikerjakan dalam keadaan darurat atau alasan yang diwajarkan seperti :

a. Terjadi kemandulan terhadap istri.

b. Istri yang tidak dapat melaksanakan kewajibannya sebagai istri.

c. Suami yang hiperseksual sehingga memerlukan penyaluran yang lebih dari seorang istri. $^{22}$

Poligami memberikan syarat adil kepada suami. Menurut Khazin Nasuha yang dimaksud dengan keadilan dalam poligami adalah adil dalam soal materi, adil dalam membagi waktu, adil membagi nafkah, yang berkaitan dalam nafkah adalah sandang, pangan dan papan, dan juga adil dalam memperlakukan keperluan batiniah istri-istrinya. Dalam hal keadilan batiniah, menurut Khazin Nasuha tidak dituntut oleh hukum islam, karena masalahnya berada diluar kemampuan manusia, sebagaimana Rasulullah SAW yang lebih cenderung rasa cintanya kepada Aisyah dibandingkan dengan istri-istri lainnya. ${ }^{23}$

Sayyid Sabiq melanjutkan pendapatnya bahwa Abu Bakar bin Arabiy berkata, memang benar bahwa adil dalam cinta di luar kesanggupan manusia (suami yang berpoligami), sebab hanya ada dalam genggaman Allah yang hanya membolak balikkannya dengan dan menurut kehendak-Nya. Begitu pula dengan bersetubuh terjadi kegairahan yang berubah-ubah, terkadang lebih bergairah dengan istri pertama dibandingkan dengan istriistri lainnya, asalkan perbuatan tersebut bukan suatu kesengajaan, tidak ada dosa bagi suami karena hal itu di luar kemampuan manusia. Keadilan dalam berpoligami adalah keadilan yang berbentuk materi atau lahiriyah karena hal tersebut dapat dikelola dengan baik dan normal oleh suami yang berpoligami.

Jadi syarat utama adalah adil terhadap istri dalam nafkah lahir dan bathin. Jangan sampai salah satunya tidak diberi cukup nafkah, maka hal itu adalah kezaliman. Yang menjadi syarat utama dalam pertimbangan poligami adalah masalah kemampuan finansial. Bagaimanapun ketika seorang suami memutuskan untuk menikah lagi yang harus dipikirkan adalah mengenai tanggung jawab nafkah dan kebutuhan hidup untuk 2 (dua) keluarga sekaligus. Nafkah tentu saja tidak berhenti sekedar bisa memberi makan dan minum untuk istri dan anak, tapi lebih dari itu bagaimana dia merencanakan anggaran kebutuhan hidup sampai kepada masalah pendidikan yang layak, rumah dan semua kebutuhan lainnya. Ketentuan mengenai keadilan hanya secara umum saja karena sangat sulit seseorang untuk

\footnotetext{
${ }^{22}$ Boedi Abdullah dan Beni Ahmad Saebani, Perkawinan dan Perceraian Keluarga Muslim, Bandung: Pustaka Setia, 2013, hlm 31.

${ }^{23}$ Aulia Muthiah, op.cit., hlm 93.
} 
dapat berlaku adil secara empiris. Misalnya masalah pembagian jatah menginap. Yang dihitung adalah malamnya atau menginapnya, bukan hubungan seksualnya. Untuk suatu keadilan tidak secara khusus diatur kerena akan kesulitan menghitung dan menimbangnya.

Kaum laki-laki diharuskan memelihara istri-istrinya dengan cara yang adil. Implikasinya jelas langsung dan benar. Para istri harus diperlakukan dengan cara yang sebaik-baiknya. Bahkan bila seorang laki-laki ternyata sudah bosan dengan istrinya atau tidak menyukainya lagi, dia tidak diperbolehkan memperlakukannya secara tidak baik sebab bisa jadi meskipun dia tidak menyukai salah satu sifatnya, dia menemukan sifat-sifat lain yang baik dan yang mengimbangi sifat yang tidak disukainya itu. Bila seorang laki-laki yang memiliki lebih dari seorang istri mencurahkan rasa cintanya lebih berat kepada salah seorang diantara keduanya secara lahiriah dia harus memperlakukannya semuanya secara baik tanpa meninggalkan sama sekali salah seorang diantara keduanya. Laki-laki yang beristri lebih dari seorang juga tidak boleh menyatakan kecenderungan cintanya kepada salah seorang diantara mereka secara mencolok sehingga menimbulkan kecemburuan dan sakit hati dan kemudian menimbulkan permusuhan diantara para istri itu. ${ }^{24}$

Dari pasal-pasal dalam Kompilasi Hukum Islam (KHI) tidak berbeda dengan Undang-Undang Perkawinan. Asas perkawinan yang terdapat dalam Kompilasi Hukum Islam (KHI) adalah asas monogami terbuka artinya jika suami tidak mampu berlaku adil terhadap hak-hak istri bila lebih dari seorang maka cukup seorang istri saja. Pasal-pasal mengenai poligami dalam Kompilasi Hukum Islam memberikan berbagai persyaratan yang ketat agar pelaku poligami tidak sewenang-wenang menerapkannya.

\section{Simpulan}

Pada prinsipnya perkawinan di Indonesia menganut asas monogami yaitu laki-laki hanya diperkenankan mengawini seorang istri saja, jadi tidak boleh memiliki lebih dari satu istri pada waktu yang bersamaan. Kekecualian terhadap berlakunya asas monogami dibuka oleh undang-undang asalkan memenuhi syarat-syarat tertentu termasuk syarat persetujuan dari istri yang sudah ada dan harus sesuai pula dengan agama yang dianut.

Poligami diperketat berdasarkan Undang-Undang Nomor 1 Tahun 1974 Tentang Perkawinan dan Kompilasi Hukum Islam (KHI) maksudnya adalah tidak semua orang dapat melakukan poligami dengan alasan yg tidak jelas atau semaunya karena ada aturan dan prosedur yang harus dipenuhi.

\footnotetext{
${ }^{24}$ Jamilah Jones dan Abu Aminah Bilal Philips, Monogami dan Poligini Dalam Islam, Jakarta: PT. Raja
} Grafindo, 1996, cet.1, hlm 55-56. 
Syarat utama dalam berpoligami adalah suami harus berlaku adil. Pada prinsipnya ada kebolehan untuk melakukan poligami yang berlaku syarat mutlak bagi seorang suami. Syarat mutlak tersebut adalah kebolehan menikah hanya kepada 4 (empat) orang istri dan dapat berlaku adil terhadap istri-istrinya. Jika syarat berlaku adil tidak bisa dipenuhi dan dilakukan maka diwajibkan untuk menikahi satu istri saja.

Idealnya kedua peraturan per undang-undangan bertujuan untuk memberikan ketentuan dan persyaratan terhadap suami yang hendak menikah lagi. Ketentuan tersebut bertujuan meminimalisir sikap kesewenang-wenangan dari pihak suami (laki-laki) terhadap istri-istri (perempuan). Demi terciptanya keluarga yang sakinah, mawaddah dan rahmah agar tujuan perkawinan terpenuhi dan tercapai.

\section{Daftar Pustaka}

\section{A. Buku}

Ahmad Sarwat, Ensiklopedia Fikih Indonesia 8, Pernikahan, Jakarta: PT. Gramedia Pustaka, Utama, 2019.

Alhamdani, Risalah Nikah, Jakarta: Pustaka Armani, 1989.

Amina Wadud Muhsin, Wanita Di dalam Al-Qur'an, Terjemahan Yaziar Radianti, Bandung: Pustaka, 1994.

Asmin, Status Perkawinan Antar Agama Ditinjau dari Undang-Undang Nomor I Tahun 1974, Jakarta: Dian Rakyat, 1986.

Aulia Muthiah, Dinamika Seputar Hukum Keluarga, Yogyakarta: Pustaka Baru Press, 2016.

Boedi Abdullah dan Beni Ahmad Saebani, Perkawinan dan Perceraian Keluarga Muslim, Bandung: Pustaka Setia, 2013.

Fazlur Rahman, Tema Pokok Al- Qur'an, Terjemahan Anas Mahyuddin, Bandung: Pustaka, 1996.

Hilman Hadikusuma, Hukum Perkawinan Indonesia, Bandung: CV. Mandar Maju, 2007.

Huzaimah T. Yanggo dan H. Anshari, Problematika Hukum Islam Kontemporer, Jakarta: Lembaga Studi Islam dan Kemasyarakatan, 1996.

Iffah Qanita Nailiya, Poligami, Berkah ataukah Musibah?, Yogyakarta: Diva Press, 2016.

Inayah Rochmaniyah, Poligami atau Monogami: Menggagas Penafsiran Ashgar Ali Terhadap Qur'an Surat An-Nisa, dalam jurnal studi ilmu-ilmu Al-Qur'an dan Hadist, 2001.

Jaih Mubarok, Pembaruan Hukum Perkawinan di Indonesia, Bandung: Simbiosa Rekatama Media, 2015.

Jamilah Jones dan Abu Aminah Bilal Philips, Monogami dan Poligini Dalam Islam, Jakarta: PT. Raja Grafindo, 1996.

Munir Fuady, Konsep Hukum Perdata, Jakarta: Raja Grafindo Persada, 2015. 
M. Quraish Shihab, Tafsir Al-Misbah, Pesan, Kesan dan Keseharian Al-Qur'an, Jakarta: Lentera Hati, 2006.

Soemiyati, Hukum Perkawinan Islam dan Undang-Undang Perkawinan, cet. 6, Yogyakarta: Liberty, 2007.

Soewondo, S, Keberadaan Pihak Ketiga, Poligami dan Permasalahan Perkawinan (Keluarga) Ditinjau dari Aspek Psikologi, dalam Munandar (ed) Bunga Rampai, Psikologi Perkembangan Kepribadian dan Bayi sampai Lanjut Usia, Jakarta: UI Press, 2001.

Tahir Mahmood, Personal Law In Islamic Countries: History, Text and Comparative Analysis, Academy of Law and Religion, 1987.

Yusuf Al- Qardhawi, Ruang Lingkup Aktivitas Wanita Muslimah, cet. 1, Jakarta: Pustaka Al-Kautsar, 1996.

\section{B. Peraturan PerUndang-undangan}

Republik Indonesia, Undang-Undang Nomor. 1 Tahun 1974 Tentang Perkawinan.

Instruksi Presiden Nomor. 1 Tahun 1991 tentang Kompilasi Hukum Islam (KHI). 